\begin{tabular}{l|l} 
Variants & $\begin{array}{l}\text { Variants } \\
\text { The Journal of the European Society for Textual } \\
\text { Scholarship }\end{array}$
\end{tabular}

12-13 | 2016

Varia

\title{
Modelling a Digital Scholarly Edition for Genetic Criticism: A Rapprochement
}

\author{
Dirk Van Hulle
}

\section{OpenEdition \\ Journals}

Electronic version

URL: http://journals.openedition.org/variants/293

DOI: $10.4000 /$ variants.293

ISSN: 1879-6095

\section{Publisher}

European Society for Textual Scholarship

\section{Printed version}

Date of publication: 31 December 2016

Number of pages: $34-56$

ISSN: 1573-3084

\section{Electronic reference}

Dirk Van Hulle, "Modelling a Digital Scholarly Edition for Genetic Criticism: A Rapprochement », Variants [Online], 12-13 | 2016, Online since 01 May 2017, connection on 01 May 2019. URL : http:// journals.openedition.org/variants/293 ; DOI : 10.4000/variants.293 


\section{Modelling a Digital Scholarly Edition for Genetic Criticism: A Rapprochement}

Dirk Van Hulle

Abstract: This essay proposes a model of genetic criticism's complex research object (writing processes) to make it manageable and develop an editorial infrastructure that facilitates research into five aspects of genetic criticism: exogenesis, endogenesis, epigenesis, microgenesis and macrogenesis. It argues that the digital paradigm can be instrumental in a rapprochement between textual scholarship and genetic criticism.. Keywords: Genetic criticism, genetic edition, scholarly editing, digital edition, drafts, editorial traditions, variant, revision.

THE ROLES OF THE EDITOR are changing rapidly in the digital paradigm. ${ }^{1}$ But there is one major role that does not change fundamentally: a scholarly editor does not "iron out" textual contingencies, but draws attention to them, thus enhancing a certain textual awareness. In this respect, scholarly editors and genetic critics have something in common. Their shared interest in the notion of "variance" is instrumental in the current convergence between these two disciplines, which manifested itself for instance at the tenth conference of the European Society for Textual Scholarship in Paris. ${ }^{2}$ For decades, genetic criticism and textual scholarship had been going their separate ways, and it looked as if never the twain would meet. During the last ten years, however, we have been working towards a rapprochement and the collaboration has proven to be mutually beneficial. Because genetic criticism duly objects to the subservient role of manuscript research in scholarly editing, the proposed

1 The research leading to these results has received funding from the Leverhulme Trust (Visiting Professorship at the University of Kent's School of European Culture and Languages) and the European Research Council under the European Union's Seventh Framework Programme (FP7/2007-2013) / ERC grant agreement $\mathrm{n}^{\circ} 313609$.

2 In November 2013, ESTS held its tenth international conference in conjunction with the Institut des textes et manuscrits modernes (ITEM) and Textes, histoire et monuments, de l'Antiquité au Moyen Âge (THEMAM). This collaboration marked a historical moment in terms of the rapprochement between textual scholarship and genetic criticism. 
model of a digital scholarly edition for genetic criticism suggests a reversal of these roles: instead of employing manuscript research in order to make an edition, digital editing can also serve as a tool for manuscript research and genetic criticism. My suggestion is not to turn the tables and reduce the function of the editor to a subservient role, but to come to a situation in which scholarly editors and genetic critics are willing to adopt — to some extent - each other's roles. As this essay will argue, the digital paradigm can be instrumental in this rapprochement.

In spite of the convergences, there are of course divergences between genetic criticism and textual scholarship in approach, aims, outcomes and so forth. First of all, many textual scholars work with mediaeval or even older manuscripts, whereas genetic criticism usually works with "modern" manuscripts, the difference being that mediaeval manuscripts, insofar as they are produced for public dissemination, function as publications; modern manuscripts are generally of a more private nature. But, evidently, there are quite a few exceptions to this rule, and it is possible to apply genetic criticism to mediaeval manuscripts that do contain autograph deletions, additions and substitutions.

Then there is the difference between the focal points. According to Daniel Ferrer, textual criticism focuses more on "repetition", whereas genetic criticism concentrates on "invention" (Ferrer 2010, 21). As a consequence, "variants" in textual criticism are more easily regarded as deviations that need to be corrected, whereas genetic criticism prefers to use the term "réécritures" (rewriting) to indicate that a change is not necessarily an error but may be part of the process of invention.

In the 1960s, when research on modern manuscripts was mainly done at the service of scholarly editing, it was necessary to make a stand against textual scholarship, and genetic criticism has the merit of having emancipated manuscript research in this respect. But now that textual scholarship fully recognizes this field of study as a discipline in its own right, this essay emphasizes what we can gain by working together with regard to several levels of variance, which will be addressed in two parts: first, exo-, endo- and epigenesis; second, micro- and macrogenesis. The essay explores a model of a digital scholarly edition that maps the interaction between these five aspects of genetic criticism, in such a way that it becomes 
a digital scholarly edition for genetic criticism. ${ }^{3}$ To this purpose I employ the term "modeling" in the sense of Willard McCarty, who follows Clifford Geertz's analytic distinction between a denotative, descriptive "model of" (e.g. a grammar describing the features of a language) and an exemplary, prescriptive "model for" such as an architectural plan: "Since modeling is fundamentally relational, the same object may in different contexts play either role: thus, e.g., the grammar may function prescriptively, as a model for correct usage, the architectural plan descriptively, as a model of an existing style" (McCarty 2004, 255). The proposed model of a digital scholarly edition for genetic criticism is - like any "model of" - a consciously and purposeful simplification in order to model digital scholarly editing as a tool for genetic criticism, instead of using "genetic criticism" as a form of textual criticism at the service of the scholarly edition. This reversal of roles requires what McCarty calls "a process of coming to know", in which models are only temporary states (2004. 256). Applying this to scholarly editions, Elena Pierazzo notes: "In order to be able to develop tools and software to support the editorial work, it is fund amentally important to produce a conceptual and functional model-of it. In this way the model-of the edition will enable the creation of a model-for the edition" (Pierazzo 2015,39 ). The model proposed in this article is not intended as a prescriptive model-for; it simply tries purposefully to simplify the complex research object of genetic criticism to make it manageable and develop an editorial infrastructure that facilitates research into exo-, endo-, epigenesis and micro- and macrogenesis. I will try to argue that one of the main roles of the editor - to enhance textual awareness - is especially relevant at the intersections between each of these five aspects. The Beckett Digital Manuscript Project (BDMP) (www.beckettarchive.org) serves as a case study, because "modeling grows out of practice, not out of theory" (McCarty 2008, 393) and because the BDMP is an example of a project that has benefited equally from the input from the theories and practices of both

3 These are five aspects of genetic criticism. They are not what Paolo D'Iorio (2010) dubbed the five constitutive parts of a digital genetic edition: (1) genetic dossiers; (2) catalogue and facsimile edition; (3) transcriptions; (4) classifications; and (5) representation of the genetic processes. The proposal is a model for a digital genetic edition's infrastructure according to a work's exo-, endo-, epi-, micro- and macrogenesis. 
genetic criticism and textual scholarship. In the resulting hybrid model, the digital edition informs the genetic analysis in the form of a printed monograph; and the genetic analysis can also inform a critical edition (as discussed in the section on epigenesis below), illustrating a rationale of reversible roles.

\section{Exogenesis, endogenesis, epigenesis}

\section{Exogenesis}

The digital medium opens up new possibilities for the integration of writers' libraries in a scholarly or genetic edition. Perhaps such an incorporation brings the scholarly edition closer to what Peter Shillingsburg called a "knowledge site" (2006, 2). A writer's creative process is often an interaction with books and notebooks. The marginalia in a book from the author's library can sometimes be linked to one of her or his own writings. Creating these paths between exo- and endogenesis involves a fair amount of critical scholarship. For instance, in Beckett's personal copy of Marcel Proust's À la recherche du temps perdu, several pages — distributed over the numerous volumes - are marked with the abbreviation "REV." in the margin. It may not be immediately clear to all readers what this means, so it could be considered a task of the editor to explain the exogenetic relevance of the marginalia. In this case, "Rev. 1" (Proust 1928, 69) stands for Revelation 1, Beckett's term for Proust's "mémoires involontaires", the moment when Marcel puts a Madeleine in his tea, which leads to an involuntary memory. Beckett counted all these revelations in the multi-volume novel and numbered them. In a digital infrastructure, an annotation could link these different instances from one revelation to the other, at a slow pace in the first volumes (from "Rev. 1" in volume one to "Rev. 6" in volume eight), until the reader reaches the last volume of the Recherche, which contains a series of revelations in short succession: "Rev. 7" on page 7, "Rev. 8" on page 9, "Rev. 9" on page 10; revelation 10 on page 18 . Here, Beckett notes the rapid succession by calling it a "bombardment" of involuntary memories. Revelation 10 is followed by one other involuntary memory, revelation 11 (on page 30). By marking these moments, Beckett made a connection, which can be made explicit, by visualizing the marginal 
"REV." marks as a string of revelations and by making the link with Beckett's own work - in this case his essay Proust, in which he enumerates the eleven revelations. As the marginalia indicate, Beckett did not read Proust passively; he invested time and effort in it and made connections between the various volumes. This form of intensive reading was an inherent part of his writing practice. To make an edition useful for genetic criticism, the digital infrastructure should therefore not only reconstruct the writer's library, but also provide a simulation of this cultural and material environment as experienced by the writer (by visualizing the paths of connections $\mathrm{s} /$ he made during the process).

A fascinating example in the case of Beckett's novels is the sentence "De nobis ipsis silemus, decidedly that should have been my motto" in the published text of The Unnamable (Beckett 2010b, 42 ). A digital genetic edition would preferably enable its users to find this sentence in all the versions, including the first manuscript in French, where the Latin quote also features on the inside of the back cover of the first notebook: "De nobis ipsis silemus / (Bacon, Intro. Novum Organon)" (Harry Ransom Center MS SB 3-10).

From an exogenetic point of view, the editor's role in the border zone between exo- and endogenesis could consist in pointing out the "creative undoing" of Immanuel Kant's name in this parenthesis. Beckett almost certainly took this sentence from Volume XI of Kants Werke (preserved in the private library of Anne Atik), where this Latin sentence is marked. But in his note, Beckett did not mention Kant's name, only Bacon's. By means of an annotation, the editor can indicate that the quotation is originally from Bacon, but that Beckett actually found it in an introductory essay by Ernst Cassirer in the last volume of the complete works by Immanuel Kant. The digitized library contains the relevant volume in which this passage is marked in pencil: "Das Wort 'De nobis ipsis silemus', das er aus Bacon entnimmt, um es der 'Kritik der reinen Vernunft' als Motto voranzusetzen" (Cassirer 1921, 5) ("The phrase 'De nobis ipsis silemus' [of ourselves, we say nothing], which he takes from Bacon to serve as a motto for the Critique of Pure Reason") (Cassirer $1981,9)$. Beckett not only marked the passage in his capacity as a "marginalist" (Ferrer 2004); he also made a separate note on this passage as an "extractor", translating/summarizing it as follows in his so-called "Whoroscope" Notebook: "Bacon's 'De $\Varangle x$ nobis 


\begin{tabular}{|c|c|c|c|c|c|c|}
\hline Version 1: MS-HRC-SB-3-10 & Quelle ost & Déplorable & $\operatorname{cette}$ & manie & de savoif & , dès qu'il se produit quelque chose, de ${ }^{\text {vouloi }}$ \\
\hline Version 2: MS-1953 & & Déplorable & & manie & & , dès qu'il se produit quelque chose, de voulo \\
\hline Version 3: MS-1971 & & Déplorable & & manie & & , dès qu'il se produit quelque chose, de voulo \\
\hline
\end{tabular}

Figure 1: Screenshot of the collation of the French manuscript and other versions, generated by CollateX as integrated in the genetic edition of L'Innommable / The Unnamable (Beckett 2013).

ipsis silemus' taken by Kant as epigraph to KRITIK der R. V." ("Whoroscope" Notebook, University of Reading, UoR MS 3000, 44"). Compared to the note in the manuscript of L'Innommable (where the Latin line is attributed to Bacon rather than to Kant), this is a case of exogenetic variance. Examples of this type indicate how useful it can be to include an author's library in a genetic edition, as they illustrate the dynamics between exo- and endogenesis. The sentence as it was incorporated in the manuscript reads: "De nobis ipsis silemus, décidément cela aurait dû être ma devise" (HRC MS SB 3-10, 44v; Becket 2013).

From an endogenetic perspective, this is not a particularly interesting sentence in terms of variance. It remains unchanged in the subsequent versions. But there are plenty of instances of variance elsewhere in the manuscript, such as the following passage (L'Innommable, sentence no. 201):

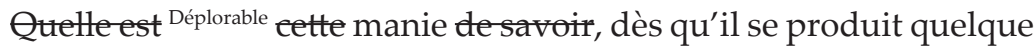
chose, de vouloir savoir quoi? [Deplorable mania, when something happens, to want to know what.] (HRC MS SB 3-10, 03v; Beckett 2013)

The integrated CollateX module enables readers to make a collation, which integrates cancellations and additions (Figure 1). ${ }^{4}$

4 The notion of "version" is used in close connection with its material support. One could argue that there are two versions in HRC MS SB 3-10; but in longer sentences, not all additions are necessarily added at the same time. Since Beckett used the same ink for both the body of the text and for the additions, it is not always possible to distinguish different revision campaigns. For this reason, different writing layers within one version are not treated as separate versions in the BDMP, but the revisions within one version do feature prominently in the collation output (with strikethrough for cancellations and 
As this collation output shows, it is possible — to some extent - to reconcile the notion of "réécritures" with "variants", despite Pierre-Marc de Biasi's objections against the latter term. ${ }^{5}$

\section{Endogenesis}

While Raymonde Debray Genette and Pierre-Marc de Biasi already suggested that it is hard to clearly separate exo- from endogenesis, Nicolas Cavaillès subsequently employed the metaphor of a river (endogenesis) and its (exogenetic) affluents. ${ }^{6}$ This metaphor corresponds to John Bryant's concept of "the fluid text" (Bryant 2002). As indicated in the introduction, when "critique génétique" had to establish itself as a discipline in its own right in the 1960s and 1970s, it was important to distinguish itself from traditional philology and textual criticism. ${ }^{7}$ In the meantime, however, the relationship

superscript for additions) and can be compared to the variants in the other versions.

5 According to de Biasi, "la critique génétique parlera de 'réécritures', d'états de rédaction' ou d'opérations génétiques': comment parler de 'variantes' en l'absence de tout invariant?" $(2000,20)$ ("genetic criticism speaks of 'rewritings', of 'redactive stages' or of 'genetic operations': how can one speak of 'variants' where the 'invariant' is completely absent?")

6 "La rivière de l'exogenèse se jette dans le fleuve de l'endogenèse, tout élément exogénétique étant progressivement incorporé au texte en cours jusqu'à s'y fondre et y suivre un destin commun avec les éléments endogénétiques qui l'environnent" (Cavaillès 2007) ("The river of exogenesis flows into the stream of endogenesis as each exogenetic element is progressively incorporated in the work in progress until it is fully integrated and shares a common destiny with the endogenetic elements surrounding it").

As Daniel Ferrer and Michael Groden note in their introduction to the collection of essays Genetic Criticism, "a decisive turning point in the history of genetic criticism was the Bibliothèque Nationale's acquisition of an important collection of Heinrich Heine manuscripts in 1966. This purchase could have been just one more addition to the rich holdings of the Département des Manuscrits if it had not occurred in the climate of political turmoil, intellectual excitement, and critical renewal that characterized the late 1960s. On the occasion of this purchase, Louis Hay, who would soon be appointed head of a small team of young scholars charged with studying the archive, published in the national press a short article - "Des manuscrits, pour quoi faire?" ("Manuscripts: So what?") - that was both defensive and programmatic. He wasted no time with traditional scholarly justifications but instead took a position relative to structuralism and the nouvelle critique. He argued that studying the final text is not the only legitimate approach and should 
between textual scholars and genetic critics increasingly resembles that of the Beckettian notion of the "pseudo-couple", which is also applicable to the characters Didi and Gogo in En attendant Godot / Waiting for Godot, who consider going separate ways at several moments, but turn out to be as inseparable as mind and body, or body and mind.

The endogenesis of En attendant Godot is marked by a notable omission, which may serve as an example to illustrate how an editor can assume the role of a genetic critic. The manuscript, preserved at the Bibliothèque nationale in Paris, contains a long passage that Beckett later cut. ${ }^{8}$ It was a slapstick conversation, ensuing after the moment when both Didi and Gogo are on the verge of asking each other the same question. They both start asking each other "Est-ce ...?" and then stop. They are extremely polite and apologize along these lines: sorry, I interrupted you. - No no, sorry, I interrupted you. And this goes on for quite a while, much longer than in the published version. It takes about two pages to find out that the next word was "que": "Est-ce que ..."; another two or three pages to find out they were going to say: "Est-ce que c'est ..."; another two pages to find out the next word was "la": "Est-ce que c'est la ..." This slapstick passage would have taken several minutes on stage. In the manuscript it takes eight pages before they find out that they both wanted to ask exactly the same question: "Est-ce que c'est la peine?" ("Is it worthwhile?"). The point of the whole scene is that by the time they find out what they each wanted to ask, they no longer remember why they wanted to ask the question in the first place.

In the context of the play, which mentions the possibility of suicide at several instances, the question as to whether "it" is worthwhile may have all kinds of existential connotations, and indeed it probably refers to the opening paragraph of Albert Camus's essay on the absurd, called Le Mythe de Sisyphe, published only six years

be complemented by genetic analysis" (Ferrer and Groden 2004, 7). In this short position statement published in Le Monde on 8 Febuary 1967, Louis Hay already mentioned the notion of a text's genetic structure, but it took another decade for the term "genetic criticism" to be generally adopted, and by 1979, the name of the discipline was fully established with the publication of Louis Hay's article "La Critique génétique: origines et perspectives" (Hay 1979).

8 For a more detailed discussion of this cut, see Van Hulle 2014a. 
before Beckett wrote his play. ${ }^{9}$ The opening sentences read: “Il n'y a qu'un problème philosophique vraiment sérieux: c'est le suicide. Juger que la vie vaut ou ne vaut pas la peine d'être vécue, c'est répondre à la question fondamentale de la philosophie" (Camus 2000, 17; emphasis added) ("There is but one truly serious philosophical problem, and that is suicide. Judging whether life is or is not worth living amounts to answering the fundamental question of philosophy") (Camus 2005, 1-2). But no matter how plausible this allusion may be, the intertextual trail is completely erased, for Beckett cut the whole passage. So whereas originally the writing strategy was to draw out the scene to such an extent that the occasion for the existential question was forgotten and the protagonists could live on, Beckett eventually decided to radically change his textual strategy. Instead of expanding the scene to the maximum, he reduced the question to the absolute minimum - a minimum that provides only just enough grammatical information to indicate that it is a question, but leaves out everything else:

Est-ce ... (Beckett 1999, 106)

Or in Beckett's own English translation:

Do you — (Beckett 2010, 71)

After this question Didi and Gogo both apologize for having interrupted each other. The result of this creative undoing and reduction to the absolute minimum is a maximum of ambiguity: we know just enough to realize that it is a question, in other words, just enough to realize that we do not know anything else. In the period of Modernism, aposiopesis - the figure of speech that works with

9 Since no reading traces have been preserved, the degree of certainty in this case is lower than in the case of the Latin quote Beckett took from his reading of Kant (see above). But the lack of reading traces does not necessarily reduce the plausibility of Beckett reading Camus's essay. Indirect endogenetic indications in the 1949 manuscript of L'Innommable corroborate the possibility that Beckett read the 1942 essay either during or shortly after the war (Van Hulle and Weller 2014, 119-20; 159-60; 165). 
unfinished sentences, originally to obtain a rhetorical effect — was increasingly used for other purposes.

In rhetoric, the intentional use of unfinished sentences shows one's eloquent mastery of the rules of rhetoric; in Modernism, the use of aposiopesis is more often used to unmask the self-deception of eloquence, to show one's linguistic scepticism and draw attention to the crisis of language in the wake of Hugo von Hofmannsthal's Chandos letter and Fritz Mauthner's Beiträge zu einer Kritik der Sprache. Take for instance the end of Katherine Mansfield's short story "The Garden Party". The protagonist has unwittingly gone through a double liminal ritual, transgressing the border between youth and adulthood and the social border between upper-middle class and working class. She seems to have understood intuitively how complex these social relations and existential transitions are, but cannot quite express this complexity. So towards the end of the story she says to her brother: "Isn't life -", without finishing the sentence. She cannot express in words what life is, but the grammatical construction implies a request for confirmation, which her brother is all too eager to give: "Isn't it, darling?" (Mansfield 2002, 349). He thus provides his sister the consolation she is yearning for, but also smothers all the ambiguity of the unfinished part of the question. While Mansfield at least gave away that it was an existential question ("Isn't life -"), Beckett's aposiopesis is even more enigmatic. The original question "Est-ce que c'est la peine" only partially fills the gap of indeterminacy. If Estragon and Vladimir stand for the Cartesian dualism of body and mind, it is their interaction that prevents them from considering suicide. Each of them wants to ask the dreaded question, and each of them interrupts the other before he can finish it.

In terms of textual scholarship, the question is how to visualize the textual trail of this aposiopesis. A possible solution is to use a synoptic survey, which is the option suggested by the Beckett Digital Manuscript Project. To avoid that users get lost in the abundance of draft versions, they have the option to choose any sentence in any version and visualize the synoptic survey of all the versions of that sentence. In case there is a sentence (or more than one sentence) that appeared in the manuscript but did not make it into the published version, this sentence is included in the survey in bold, added to the first preceding sentence that did make 


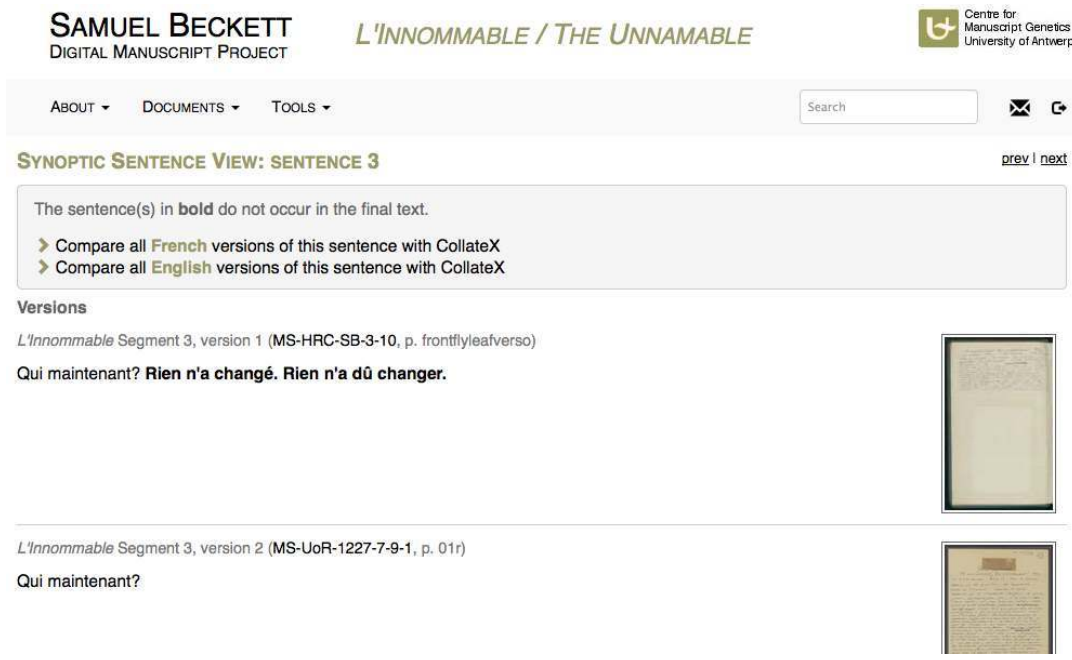

Figure 2: Screenshot of the synoptic sentence view in L'Innommable / The

Unnamable in the Beckett Digital Manuscript Project (Beckett 2013)

it into the published version. For instance, in the opening paragraph of L'Innommable the sentences “Rien n'a changé. Rien n'a dû changer" never made it into the published version, but the preceding question "Qui maintenant?" did. So, the transcription of "Qui maintenant?" is accompanied by those two sentences, marked in bold, to indicate that they can only be found in this manuscript version (see Figure 2).

The same method of marking variance could theoretically be applied to the eight-page omission in the genesis of En attendant Godot. The synoptic sentence view will then be completely dominated by the equivalent of eight pages of text in bold. As a result, this might defeat the purpose of giving users a synoptic survey, but it will draw attention the creative undoing. An alternative is to indicate that a major passage was cut, but instead of including the entire text, the edition can alert readers to this omission (with a note: "This is the start of a long, eight-page dialogue that did not make it into the published version") and provide users with a link that takes them directly to the relevant passage in the transcription. This way the digital edition serves as a tool for genetic criticism. 
VLADIMIR Je t'ai coupé.

ESTRAGON Au contraire.

Ils se regardent avec colère.

VLadimir Voyons, pas de cérémonie. ESTRAGON Ne sois pas têtu, voyons.

VLADIMIR avec force: Achève ta phrase, je te dis.

ESTRAGON de même: Achève la tienne.

Silence. Ils vont l'un vers l'autre, s'arrêtent.

VLADIMIR Misérable!

ESTRAGoN C'est ça, engueulons-nous. Echange d'injures.

Silence. Maintenant raccommodonsnous.
VLADIMIR I interrupted you. ESTRAGON On the contrary. They glare at each other angrily. VLADIMIR Ceremonious ape! ESTRAGON Punctilious pig! VLADIMIR Finish your phrase, I tell you!

ESTRAGON Finish your own!

Silence. They draw closer, halt. VLADIMIR Moron!

ESTRAGON That's the idea, let's abuse each other.

They turn, move apart, turn again and face each other. VLADIMIR Moron! ESTRAGON Vermin! VLADIMIR Abortion! ESTRAGON Morpion! VLADIMIR Sewer-rat! ESTRAGON Curate! VLADIMIR Cretin! ESTRAGON with finality: Crritic! VLADIMIR Oh!

He wilts, vanquished, and turns away. ESTRAGON Now let's make it up.

Figure 3: Passage from the trilingual edition of Beckett's En attendant Godot / Waiting for Godot / Warten auf Godot $(2003,186)$.

\section{Epigenesis}

From the perspective of genetic criticism, it may seem a technical detail to find solutions for this visualization, but at the same time finding ways to draw readers' attention to the dead ends in the genesis is a crucial aspect of the study of writing processes. The question that was cut from the manuscript, "Est-ce que c'est la peine?", when taken out of its context and applied to the theme of "variance", sounds like a critical question that one could very well imagine textual scholars and genetic critics are asking one another: to study "variants" or "réécritures", is that really worthwhile? The answer is clear: of course it is. Both of them will argue that their respective discipline is interested in what happened after Beckett made his cut. The original long passage was replaced by a shorter scene in which Didi and Gogo abuse each other. They call each other moron, vermin, abortion, morpion, sewer rat; and finally 
Gogo calls Didi a "Crritic!" After this final blow, Didi can only reply with an indignant "Oh!" Applied to the exchanges between genetic critics and textual critics the insult "Crritic!" works both ways, so it does not matter who plays Didi and who plays Gogo. The roles are interchangeable. Both of them will be interested to know that the English translation, made by Beckett himself, differs from the French original. The French stage direction simply reads: "Echange d'injures" (Figure 3). Typographically, in a parallel presentation, this results in a blank space in the French version - allowing for free improvisation by the actors - alongside a written-out version in English. This is an instance of variance that is of interest to textual and genetic critics alike.

One could object that these are not modern manuscripts and that the change took place after the first publication, after the "bon à tirer" moment, that it is not in other words strictly speaking part of the "avant-texte" or the genetic dossier. But on the other hand, since the English version is Beckett's own translation, one could also argue that it is a continuation of the genesis after publication. Moreover, Beckett also adapted the French text. A copy that was offered for auction at Sotheby's in 1990 shows how Beckett annotated his prompt copy of the first edition (now preserved at Trinity College, Dublin), adding the abusive terms "V. Andouille I E. Tordu | V. Crétin | E. Curé | V. Dégueulasse | E. Micheton | V. Ordure I E. Architecte" by hand (Sotheby's 1990, 209).

Even though this is usually seen as the domain of textual scholars, this grey area of the "epigenesis" (the continuation of the genesis after the "bon à tirer" moment, the moment the author decided the text was ready to be printed) is an excellent space for textual criticism and genetic criticism to converge (see Figure 4).

In biology, epigenetics is a term denoting the discipline that studies the changes in the phenotype or the expression of the gene, caused by external circumstances, which nonetheless do not change the DNA sequence. ${ }^{10}$ The environment does not change the DNA but it does have an impact on the way the genes express themselves in the phenotype. For instance, it has been proven that famine in a certain generation of the population (say, generation 1) leads to an increased risk of diabetes in their grandchildren (generation 3).

10 For a more detailed discussion of the correspondences between biological and textual epigenetics, see Van Hulle 2014b, 216-17. 


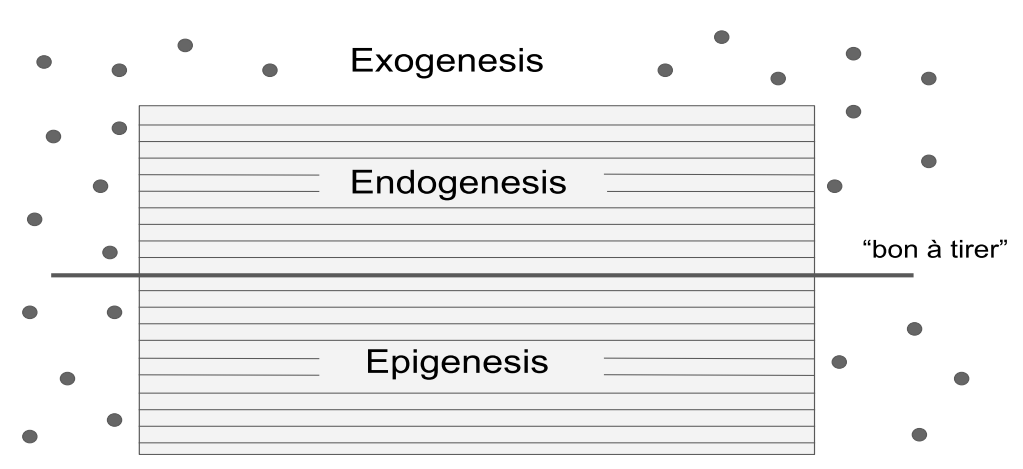

Figure 4: Modelling a digital scholarly edition for genetic criticism, including exo-, endo- and epigenesis.

Similarly, when for instance On the Origin of Species was published in 1859, the criticism in Charles Darwin's environment had such an impact on him that it changed the phenotype of his book on five subsequent occasions: he kept reacting to this criticism by rewriting his book. As a consequence, each edition published in his lifetime is different.

In literature, there are numerous examples of epigenetic variance. If a playwright not only writes but also directs his plays, he often uses the rehearsals to keep changing his text, even if it is already published. In the case of Waiting for Godot, Beckett first directed his own play in German in Berlin. During the rehearsals he made changes to the text, notably to the "Echange d'injures" between Didi and Gogo. The published version of the translation reads: "Schurke! Würstchen! Saftsack! Giftzwerg! Rotzlöffel! Rindsknochen! Mistbiene! Ober...forstinspektor!" In his own copy, Beckett manually changed this whole series into: "Streithammel | Querulant | Stinkstiefel | Giftnickel | Brechmittel | Pestbeule | Scheisskert Parasit! (Pa .. Pa. Paläolithiker)" (Beckett 2006, 92).

Before critics can ask the question whether these changes should be treated as "réécritures", as "variants", or perhaps even as "variations on a theme", they have to be aware of this kind of revision sites in the first place and need to have access to these textual instances as well as the means to discuss them. Providing the tools to enhance this textual awareness is an important role of the editor. In this case, the publishing house Suhrkamp not only published Beckett's 
copy in a facsimile edition, but also adapted the text according to Beckett's "réécritures" (incorporating his handwritten changes in subsequent editions) and produced a trilingual edition (1963). Still, when Beckett received the trilingual edition, he did not fail to remark that Suhrkamp had made use of the expurgated version of the English text. In 1965, Faber and Faber finally published the unexpurgated version, which Suhrkamp subsequently used in their paperback version of the trilingual edition (1971).

As these examples illustrate, there is an urgent need for a critical edition and my suggestion is that this critical edition should be both bilingual and informed by genetic criticism. Or, seen from another perspective and applying the rationale of reversible roles, these examples show that there is an urgent need for a genetic approach informed by a bilingual critical edition. Such a genetically informed bilingual edition is certainly feasible and can build on the Beckett Digital Manuscript Project to offer readers an insight into both the micro- and the macrogenesis.

\section{Micro- and macrogenesis}

\section{Microgenesis}

Hans Walter Gabler has argued that a distinction should be made between "text editions" and "manuscript editions" (see his contribution in this issue of Variants). If one tries to apply this division to concrete projects such as the case study at issue, the BDMP would have to be categorized - at least in the first instance - as a manuscript edition: one of its two main purposes is to reunite digitally the dispersed manuscripts of Samuel Beckett's works. But the other purpose is to facilitate their examination. In addition to digital facsimiles and topographic transcriptions, it also includes linear transcriptions of all the versions (encoded in XML-TEI). The sentence generally serves as a functional unit of comparison. Readers can choose any sentence and study all the versions of this unit in the synoptic sentence view, and have the option to use this synoptic view as the basis for automatic collation with CollateX. ${ }^{11}$ The result comes very close to what Hans Walter Gabler terms a text edition.

11 This feature was incorporated and is still being optimalized in close collaboration with the developer of CollateX, Ronald Dekker 
Although it is necessary and useful to establish a typology in order to develop a theoretical framework for digital scholarly editions, the borders between the types or categories are not necessarily impermeable. The digital medium actually enables both genetic critics and textual critics to use the edition according to the nature of the research object they wish to study, focusing either on the manuscript or on the text, and in accordance with Daniel Ferrer's distinction that a manuscript is not a text but a protocol for making a text (Ferrer 2011,43). The digital genetic edition does not have to be either an archive edition or a text edition; it can be a continuum between the two. It is up to the reader or researcher to decide in which capacity it is used (Van Hulle 2009; see also Kenneth Price's suggestion to use the term "arsenal" [Price 2009]).

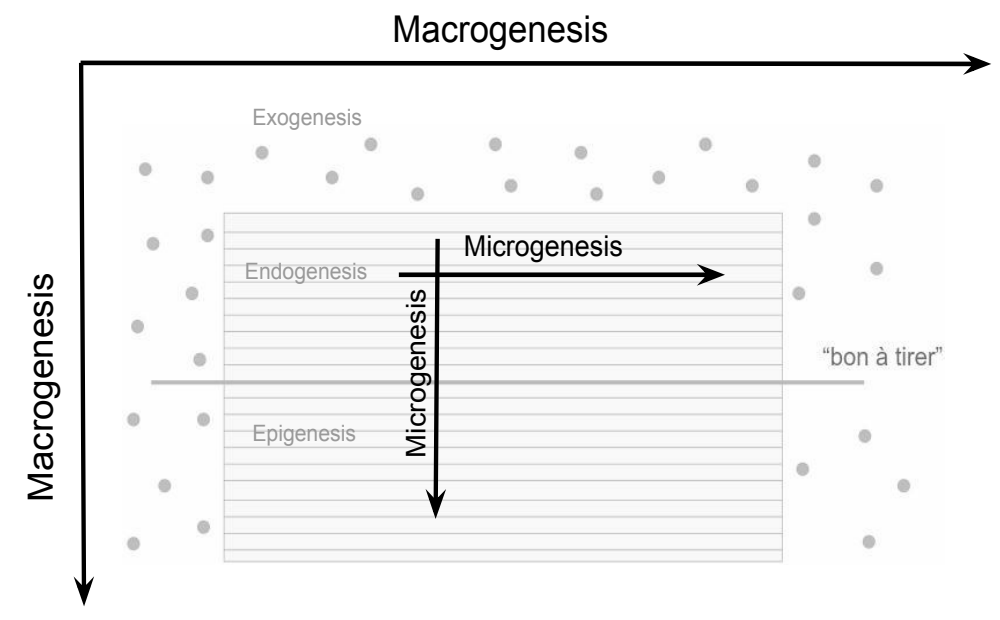

Figure 5: Modelling a digital scholarly edition for genetic criticism, including exo-, endo-, epigenesis, as well as microgenesis and macrogenesis.

The flexibility of the digital medium, which makes it so suitable for scholarly editing, complements the relative fixity of print editions. Print however continues to be an asset for readers' editions, because the human brain maps the book's topography while reading in a way that digital does not. ${ }^{12}$ The urgent need for

(Huygens ING, The Hague).

${ }_{12}$ A recent study at the University of Utrecht (led by Daniel Janssen) has shown that readers who read a story from a print edition 
a critical edition of Beckett's works that I identified earlier could combine the qualities of both media for the respective purposes to which they are beneficial. The print version can take shape in a bilingual edition, offering the original and Beckett's self-translation in parallel presentation. In addition to a critical apparatus, the system of "revision sites" and "revision narratives" introduced by John Bryant and Haskell Springer in their edition of Herman Melville's Moby Dick (2007) would be a suitable way of enhancing readers' textual awareness by drawing attention to instances of significant textual variance and explaining the genetic importance of the "réécriture", "variant" or "variation". To combine the fixity of print with the flexibility of the digital genetic edition, the revision narrative can also be consulted online, enabling readers to study the manuscripts if they so desire. The print version does not need to be burdened with a critical apparatus either, as readers can always consult the BDMP's synoptic survey online. Instead of turning the critical apparatus into the dullest part of a critical edition, the digital edition can offer automatic collation as a tool to help users discover complex and therefore interesting textual instances in the manuscripts and other textual versions.

\section{Macrogenesis}

This combination does not only work on the level of the microgenesis (the processing of a particular exogenetic source text; the revision history of one specific textual instance across endogenetic and/or epigenetic versions; the "réécritures" or revisions within one single version), but can also be applied to the macrogenesis (the genesis of the work in its entirety across multiple versions i.e. by combining large textual units along the syntagmatic axis with the development along the paradigmatic axis on a macrolevel; Figure 5).

For instance, when Beckett had completed the first two dozen of pages of the first notebook containing the manuscript of L'Innommable, he suddenly had an idea for the end of the novel. He

are better at reconstructing the plot than readers who read it from an e-book (see "E-book of gewoon boek", <http://www.een.be/programmas/ook-getest-op-mensen/e-book-of-gewoon-boek>, accessed 21 November 2014). 


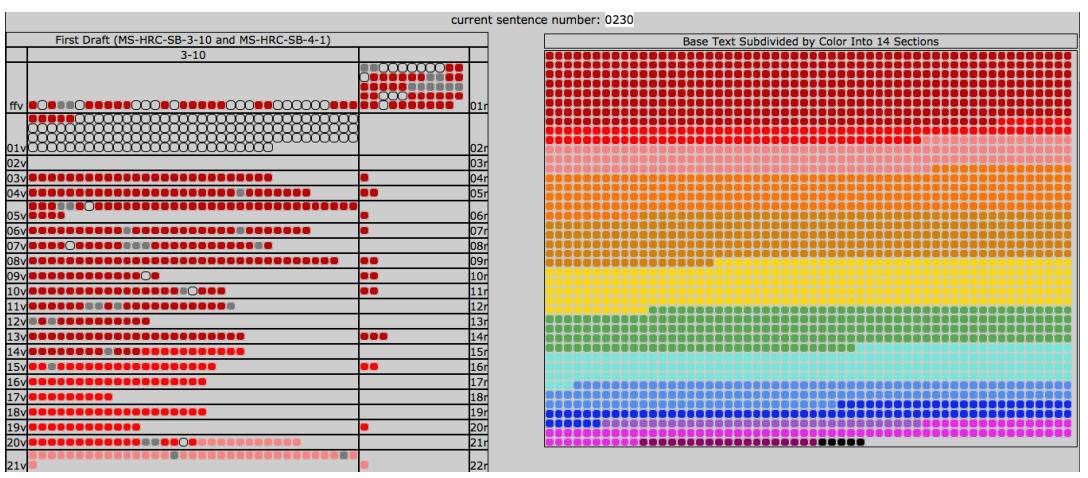

Figure 6: Document-oriented, macrogenetic visualization of the writing process of the French manuscript of Beckett's L'Innommable / The Unnamable. For a colour image, see http://www.becketarchive.org/writingsequenceofinnommable.jsp.

wrote this idea on two separate sheets of paper and pasted them into the back of the first notebook. Eventually, he decided not to use this passage for the end (though he did use it for a passage towards the end of the novel). A macrogenetic approach maps the interaction between the topography of the notebook and the development of the narrative. In this particular case, this implies a visualization that shows how the two pages pasted into the back of the first L'Innommable notebook were actually written rather early in the writing process (after two dozen of pages), in spite of the impression the topography (the back of the notebook) may create.

To visualize this macrogenetic manoeuvre, the BDMP makes use of the same numbering system (in the XML encoding) that enables readers to compare sentences in the synoptic survey. The reader has the option between a document-oriented or a text-oriented visualization.

The document-oriented visualization (Figure 6) focuses on the order of sentences as they are arranged on the manuscript page. It presents each sentence as a bullet linked to its respective sentence number, based on the order of sentences in the base text, and colour-coded according to fourteen narrative sequences into which the novel has been divided (Van Hulle and Weller 2014, 95-6). ${ }^{13}$ Sentences in the manuscript that have not made it into the

${ }^{13}$ I owe a debt of gratitude to Wout Dillen and Vincent Neyt for their 


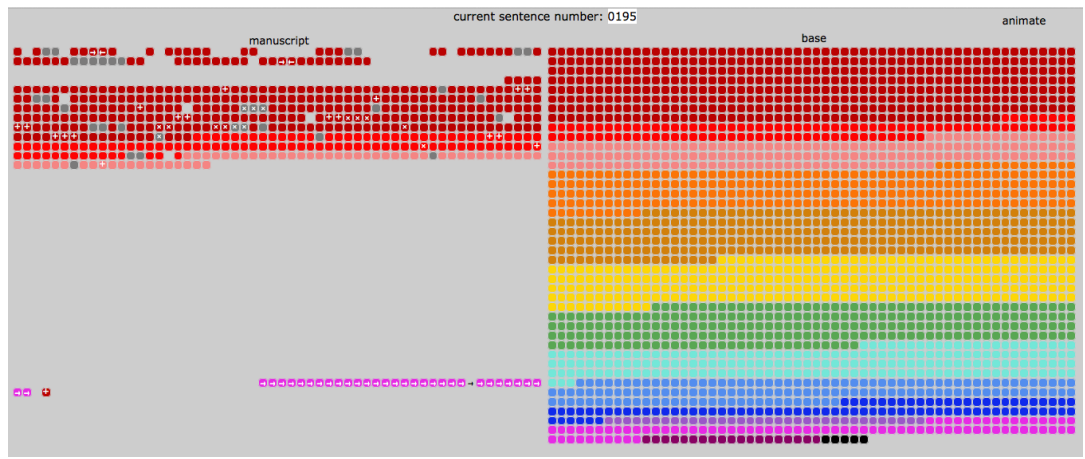

Figure 7: Text-oriented, macrogenetic visualization of the writing process of the French manuscript of Beckett's L'Innommable/The Unnamable. (The screenshot is a still of what is presented as an animation online, see http:// www.beckettarchive.org/writingsequenceofinnommable.jsp.)

published text are marked in grey in order to map the dead ends or culs-de-sac in the writing process. ${ }^{14}$

The text-oriented approach (Figure 7) focuses on the order of sentences in the text of the manuscript (compared to the base text), not the order of sentences as arranged on the page. It takes into account loose jottings, related to a specific sentence; sentences that are crossed out in their entirety; and the movement of sentences in relation to the base text. Since the goal of genetic criticism is to study the dynamics of the writing process, it may be useful to visualize the macrogenesis in a dynamic way as an animated presentation (see http://www.beckettarchive.org/writingsequenceofinnommable.jsp).

This way another level of variance can be visualized: the difference between the topology of the document and the chronology of the text.

invaluable help with the technical realization of this visualization tool. Clicking on the bullet brings the reader directly to the relevant sentence in the manuscript.

14 Thanks to genetic editing, however, these are not really dead ends. Even though they did not make it into the published text, these cuts are instances of creative undoing which typically serve as engines that propel the creative process. 


\section{Conclusion}

These developments may raise (and have raised) the question whether this kind of schematic visualization or animation can "still" be called scholarly editing, as well as the question whether it is "already" part of scholarly editing. ${ }^{15}$ The tension between these two questions indicates not just how the digital medium has become the medium for scholarly editions, but also how this new medium constantly pushes the limits of what we regard as "scholarly editing" - and how it facilitates the rapprochement between scholarly editing and genetic criticism. It allows us to look for new editorial ways to give shape to one of the most complex aspects in genetic criticism: how to visualize macrogenetic variance. Once one becomes more familiar with an author's manuscripts, one's attention tends to become absorbed by the tiniest details in the handwriting. Even digital collation is relatively "micro"-focused. To really help students and interested readers find their way in the labyrinth of the manuscripts, the proposed model tries to map not only the exo- and endogenesis, but also the epigenesis, not only the micro-, but also the macrogenesis as an intrinsic part of digital scholarly editing to enable and facilitate genetic criticism.

\section{Bibliography}

Beckett, Samuel. 1984. Disjecta. Ed. Ruby Cohn. New York: Grove Press.

15 The papers read at the "Digitale genetische Editionen (in der Praxis)" colloquium at the Schweizerischen Literurarchiv in Bern (4-5 September 2014) triggered interesting replies from the respondents, such as this question by Almuth Grésillon: "Ist das noch edieren?" ("Is this still editing?") and the counter-question by Patrick Sahle: "Ist das schon edieren?" ("Is this editing yet?"). The question "Ist das noch edieren?" was a direct reaction to the observation that many of the concrete suggestions in the presentations were attempts to visualize macrogenetic patterns in schematic ways. The mere fact that some of the participants regarded this as being part of digital scholarly editing and that at least one respondent suggested it was not, may also imply that the notion of "macrogenesis" is actually an excellent middle ground where genetic criticism and scholarly editing can meet. 
—_. 1999. En attendant Godot. Paris: Éditions de Minuit.

—. 2003. En attendant Godot / Waiting for Godot / Warten auf Godot. Frankfurt am Main: Suhrkamp.

—_. 2006. Warten auf Godot. Facsimile edition. Frankfurt am Main: Suhrkamp.

—_. 2010a. Waiting for Godot. London: Faber and Faber.

— . 2010b. The Unnamable. Ed. Steven Connor. London: Faber and Faber.

—_. 2013. L'Innommable / The Unnamable: A Digital Genetic Edition. Eds. Dirk Van Hulle, Shane Weller and Vincent Neyt. The Beckett Digital Manuscript Project, Module 2. Brussels: University Press Antwerp (ASP/UPA), 2013, <http://www.beckettarchive. org $>$.

Bryant, John. 2002. The Fluid Text: A Theory of Revision and Editing for Book and Screen. Ann Arbor: University of Michigan Press.

Camus, Albert. 2000. Le Mythe de Sisyphe. Essai sur l'absurde. Paris: Gallimard.

—_. 2005. The Myth of Sisyphus. Trans. Justin O'Brien. London: Penguin Books.

Cassirer, Ernst. 1921. Kants Leben und Lehre. Berlin: Bruno Cassirer.

__. 1981. Kant's Life and Thought. Trans. James Haden. New Haven and London; Yale University Press.

Cavaillès, Nicolas. 2007. "L'Exogenèse: Cas du Précis de decomposition de Cioran". Revue Recto/Verso, 1, <http://www.revuerectoverso.com/IMG/pdf/Exogenese.pdf $>$.

De Biasi, Pierre-Marc. 1998. “Qu'est-ce qu'un brouillon? Le cas Flaubert: Essay de typologie fonctionnelle des documents de genèse". In Michel Contat and Daniel Ferrer, eds. Pourquoi la critique génétique? Méthodes, théories. Paris: CNRS Editions, pp. 31-60.

—_. 2000. La génétique des textes, Paris: Nathan.

Debray Genette, Raymonde. 1979. “Genèse et poétique: Le cas Flaubert". In Louis Hay, ed. Essais de critique génétique. Paris: Flammarion, pp. 21-67.

D'Iorio, Paolo. 2010. “Qu'est-ce qu'un édition génétique numérique?" Génésis, 30, pp. 49-53, <https://genesis.revues.org/116>.

D'Iorio, Paolo and Daniel Ferrer, eds. 2001. Bibliothèques d'écrivains. Paris: CNRS Editions. 
Ferrer, Daniel. 2004. “Towards a Marginalist Economy of Textual Genesis". In Dirk Van Hulle and Wim Van Mierlo, eds. Reading Notes. Special issue of Variants, 2/3, pp. 7-18.

— . 2010. "Critique génétique et philologie: Racine de la différence". Genesis, 30, pp. 21-23.

—_. 2011. Logiques du brouillon: Modèles pour une critique génétique. Paris: Seuil.

Ferrer, Daniel and Michael Groden. "Introduction". In Jed Depman, Daniel Ferrer and Michael Groden, eds. Genetic Criticism: Texts and Avant-textes. Philadelphia: University of Pennsylvania Press, pp. 1-16.

Gontarski, S. E. 2006. "Greying the Canon: Beckett in Performance." In Beckett after Beckett. Edited by S. E. Gontarski and Anthony Uhlmann. Gainesville: University Press of Florida, pp. 141-57.

Hay, Louis. 1979. "La Critique génétique: Origines et perspectives." In Louis Hay, ed. Essais de critique génétique. Paris: Flammarion, pp. 227-36.

Mansfield, Katherine. 2002. Selected Stories. Ed. by Angela Smith. Oxford: Oxford University Press.

McCarty, Willard. 2004. "Modeling: A Study in Words and Meanings". In Susan Schreibman, Ray Siemens and John Unsworth, eds. A Companion to Digital Humanities. Oxford: Blackwell, pp. 254-70, <http://www.digitalhumanities.org/companion/>.

McCarty, Willard. 2008. "Knowing ... : Modeling in Literary Studies". In Susan Schreibman and Ray Siemens, eds. A Companion to Digital Literary Studies. Oxford: Blackwell, pp. 391-404, <http:// www.digitalhumanities.org/companionDLS/>.

Melville, Herman. 2007. Moby-Dick. Eds. John Bryant and Haskell Springer. New York: Pearson / Longman.

Pierazzo, Eleno. 2015. Digital Scholarly Editing: Theories, Models and Methods. Farnham: Ashgate.

Price, Kenneth. 2009. "Edition, Project, Database, Archive, Thematic Research Collection: What's in a Name?" Digital Humanities Quarterly, 3(3), <http://www.digitalhumanities.org/dhq/ vol/3/3/000053/000053.html>.

Proust, Marcel. 1928. À la recherche du temps perdu: Du Côté de chez Swann. Paris: Éditions de la Nouvelle Revue Française. 
Shillingsburg, Peter. 2006. From Gutenberg to Google: Electronic Representations of Literary Texts. Cambridge: Cambridge University Press.

Sotheby's: English Literature and History (London, 13 December 1990). 1990. London: Sotheby's.

Van Hulle, Dirk. 2009. "Editie en/of archief: Moderne manuscripten in een digitale architectuur." Verslagen en mededelingen van de Koninklijke Academie voor Nederlandse Taal- en Letterkunde, 119(2), pp. 163-78.

- 2014a. "Textual Scars: Beckett, Genetic Criticism and Textual Scholarship." In S. E. Gontarski, ed. The Edinburgh Companion to Samuel Beckett and the Arts. Edinburgh: Edinburgh University Press, pp. 306-19.

— . 2014b. Modern Manuscripts: The Extended Mind and Creative Undoing from Darwin to Beckett and Beyond. London: Bloomsbury. Van Hulle, Dirk and Wim Van Mierlo, eds. 2004. Reading Notes. Special issue of Variants, 2/3.

Van Hulle, Dirk and Shane Weller. 2014. The Making of Samuel Beckett's L'Innommable/The Unnamable. The Beckett Digital Manuscript Project 2. London: Bloomsbury. 